\title{
Behavioural responses to chemical cues of predation risk in a three-trophic-level Baltic Sea food chain
}

\author{
Gunilla Ejdung* \\ Department of Zoology and Department of Systems Ecology" , Stockholm University, S-10691 Stockholm, Sweden
}

\begin{abstract}
Behavioural responses of 2 Baltic benthic crustaceans to chemical substances from predators were studied using infrared video-recording in the laboratory. This is the first study of behavioural responses to species-specific chemical substances in a 3-trophic-level food chain. Exposure to chemical substances from a predatory fish, the short-horned sculpin Myoxocephalus scorpius (L.), caused the isopod Saduria entomon (L.) to remain buried in the sediment most of the time and decreased its foraging success on the amphipod Monoporeia affinis (Lindström). $M$. affinis decreased its swimming activity when exposed to water from $S$. entomon feeding on $M$. affinis, whereas water from unfed $S$. entomon had no such effect.
\end{abstract}

KEY WORDS: Chemical cues - Three-trophic-level food chain - Monoporeia affinis - Saduria entomon Fish Benthos Behaviour Baltic Sea

\section{INTRODUCTION}

In the aquatic environment, the use of chemical cues is probably universal (Dodson et al. 1994). Prey and predators can often discover and localise each other through chemical cues, which may profoundly influence their interactions (Sih 1986, Rittschof 1993, Abrahams 1994, Rochette et al. 1994). The life-history strategy (Crowl \& Covich 1990), behaviour (Folt \& Goldman 1981, Dodson et al. 1994, Duval et al. 1994), activity pattern (Sih 1986, Holomuzki \& Short 1988) and morphology (Appleton \& Palmer 1988, Larsson \& Dodson 1993) of potential prey may be significantly affected by the presence of predators. Conventional optimal foraging theory predicts that predators should maximise their net rate of energy intake (Hughes 1980). Factors influencing the rate of energetic acquisition, e.g. energy reserves and potential risks from predators, have been taken into consideration (Sih 1982, Vadas et al. 1994) and also included in models (Mangel \& Clark 1986, Gilliam \& Fraser 1987, Burrows \& Hughes 1991,

\footnotetext{
•E-mail: gunilla@system.ecology.su.se

- Present address
}

McNamara \& Houston 1992). To maximise fitness, foragers should weigh potential energy gain against mortality risk (Dill \& Fraser 1984, Abrahams \& Dill 1989).

Predation risk can be perceived through visual, mechanical and chemical cues (Busdosh et al. 1982). Many aquatic invertebrates have small, poorly developed, non-image-forming eyes, sensitive mainly to changes in light intensity (Dodson et al. 1994), but possess well-developed chemoreceptors (Laverack \& Ardill 1965, Pynnönen 1985, Larsson \& Dodson 1993, Kaufman 1994). Chemical receptors and chemical cues can be used in darkness and by animals that have poor vision or do not see at all. Chemical cues may be molecules large enough to be species-specific, such as proteins (Atema 1988). Concentration and/or composition of the cue makes it possible to recognise a predator and whether it is actively feeding, has recently fed or is starving (Phillips 1978, Appelberg et al. 1993). Alarm substances, originating from predator-mediated release by injured conspecifics, reveal the presence of a predator (Appleton \& Palmer 1988, Alexander \& Covich 1991a, Hugie et al. 1991, Houtman \& Dill 1994, Vadas et al. 1994) and may affect behaviour, growth rate, and morphology (Sih 1986, Appleton \& Palmer 1988). 
The question addressed here is whether chemical substances from predators influence the behaviour of 2 Baltic benthic crustaceans. Thus, the aims of my experiments were to determine: (1) whether exposure to chemical substances from a predatory fish, the shorthorned sculpin Myoxocephalus scorpius (L.), affected the behaviour of the predatory isopod Saduria entomon (L.); (2) whether the rate of predation by $S$. entomon on its natural prey, the amphipod Monoporeia affinis (Lindström), changed in fish conditioned water; (3) whether exposure to the odour of starved $S$. entomon affected the activity and behaviour of $M$. affinis; and (4) whether $M$. affinis reacted to waterborne substances from $S$. entomon and its prey while the isopod killed, ate and digested individuals of $M$. affinis. The species chosen represent a naturally occurring 3trophic-level system found in the species-poor Baltic benthic community. To my knowledge, this is the first study of the importance of behavioural responses to species-specific chemicals in a 3-trophic-level food chain.

\section{MATERIAL AND METHODS}

Study area, species studied, collection and treatment of sediment and animals. This study was carried out in the northwestern Baltic proper at the Askö Laboratory on the east coast of Sweden $\left(58^{\circ} 49^{\prime} \mathrm{N}\right.$, $17^{\circ} 38^{\prime} \mathrm{E}$ ). On the species-poor sub-thermocline benthic bottoms in this area, the amphipod Monoporeia affinis is one of the most abundant and productive species, with a natural abundance in 1981 to 1993 of 80 to $21001 \mathrm{yr}$ old $(1+) \mathrm{M}$. affinis $\mathrm{m}^{-2}$ at $27 \mathrm{~m}$ depth in the Askö area (station 6017 of the National Swedish Environmental Monitoring Program). $M$. affinis is a nightactive surface-forager that mainly dwells in the upper $5 \mathrm{~cm}$ of the sediment (Hill \& Elmgren 1987, Lopez \& Elmgren 1989, Lindström et al. 1991). Late in the evening, the amphipods leave the bottom for excursions into the water column (Lindström \& Lindström 1980). When they return to the bottom, they dig a new hole, in which they lie on the back. By moving the pleopods, water is efficiently circulated into the burrow (Lindström 1991).

Abundances of the predatory isopod Saduria entomon ranged from 0 to $110 \mathrm{ind} . \mathrm{m}^{-2}$ during the same period (Cederwall 1990, pers. comm.). In the late 1980s and early 1990s, S. entomon was easily caught in the study area, but by the summer of 1994 , when this study was performed, sufficient numbers could not be obtained. $S$. entomon was therefore collected in the Norrby archipelago, northern Bothnian Sea $\left(63^{\circ} 30^{\prime} \mathrm{N}\right.$, $19^{\circ} 50^{\prime} \mathrm{E}$ ), at a salinity of ca 4 psu. In the laboratory, the euryhaline (Lockwood \& Croghan 1957) S. entomon acclimatised almost without mortality to a gradual increase in salinity from 4 to 6.5 psu, the salinity in the Askö area. S. entomon is a predator and a scavenger that possesses an array of feeding behaviours, and is reported to be mainly nocturnal (Westin \& Aneer 1987). The eyes of $S$. entomon are small, with maximal sensitivity to green wavelengths, which dominate at the depths where this isopod lives. However, food is located and recognised via chemoreceptors and chemical cues (Pynnönen 1985). S. entomon has 2 types of chemoreceptors, viz. distance chemoreceptors on the first antennae and contact chemoreceptors on the mouth parts. Intact antennae are crucial for bilateral antennular chemoreception (Pynnönen 1985) of odours, such as those coming from dead fish. Small $S$. entomon avoid water from larger cannibalistic conspecifics (Leonardsson 1991).

In the Baltic, Saduria entomon is the main diet for the short-horned sculpin Myoxocephalus scorpius (Haahtela 1990) and is also eaten by the fourhorn sculpin M. quadricornis (L.) (Westin 1970, Aneer 1975). The short-horned sculpins used in the experiments were caught with a gill net and kept in $60 \mathrm{l}$ containers at ca $7^{\circ} \mathrm{C}$.

Sediment and Monoporeia affinis were collected close to the laboratory, at $30 \mathrm{~m}$ depth, using a benthic sled (Blomqvist \& Lundgren 1996). The sediment was sieved through a $300 \mu \mathrm{m}$ metal mesh net and kept cold prior to use. The amphipods were stored in aerated water in a thermostat controlled room $\left(7^{\circ} \mathrm{C}\right)$, with a daily $17 \mathrm{~h}$ light: $7 \mathrm{~h}$ dark cycle simulated with a dim green light; the same light cycle as used in the experiment. The day before the start of the experiment, individual $M$. affinis were randomly picked in batches of 5 and inspected under a stereomicroscope to ensure that only intact amphipods were used.

The energy reserves of a predator often affect its foraging intensity (McNamara \& Houston 1986). Even though Leonardsson (1991) found no difference in consumption rates for starved or fed Saduria entomon, the isopods in my experiments were deprived of food $2 \mathrm{~d}$ prior to the start of the experiment. $S$. entomon can survive starvation for months with little mortality (author's unpubl. obs.). Only non-gravid isopods with intact antennae were used.

General experimental set-up. Square plastic aquaria, placed in two 1001 troughs $\left(0.88 \mathrm{~m}^{2}\right)$ (Fig. 1), were used as containers. The aquaria had a sediment area of $310 \mathrm{~cm}^{2}$ and $11 \mathrm{~cm}$ high walls, each of which had a $75 \mathrm{~cm}^{2}$ rectangular hole covered with a $0.2 \mathrm{~mm}$ mesh net, allowing water but not animals to pass through. The sediment depth was $3.5 \mathrm{~cm}$, just reaching the holes in the aquarium walls. Below the 1001 troughs, two $140 \mathrm{l}$ troughs $\left(0.93 \mathrm{~m}^{2}\right)$, one containing sea water and one prepared water, were placed. Sea 


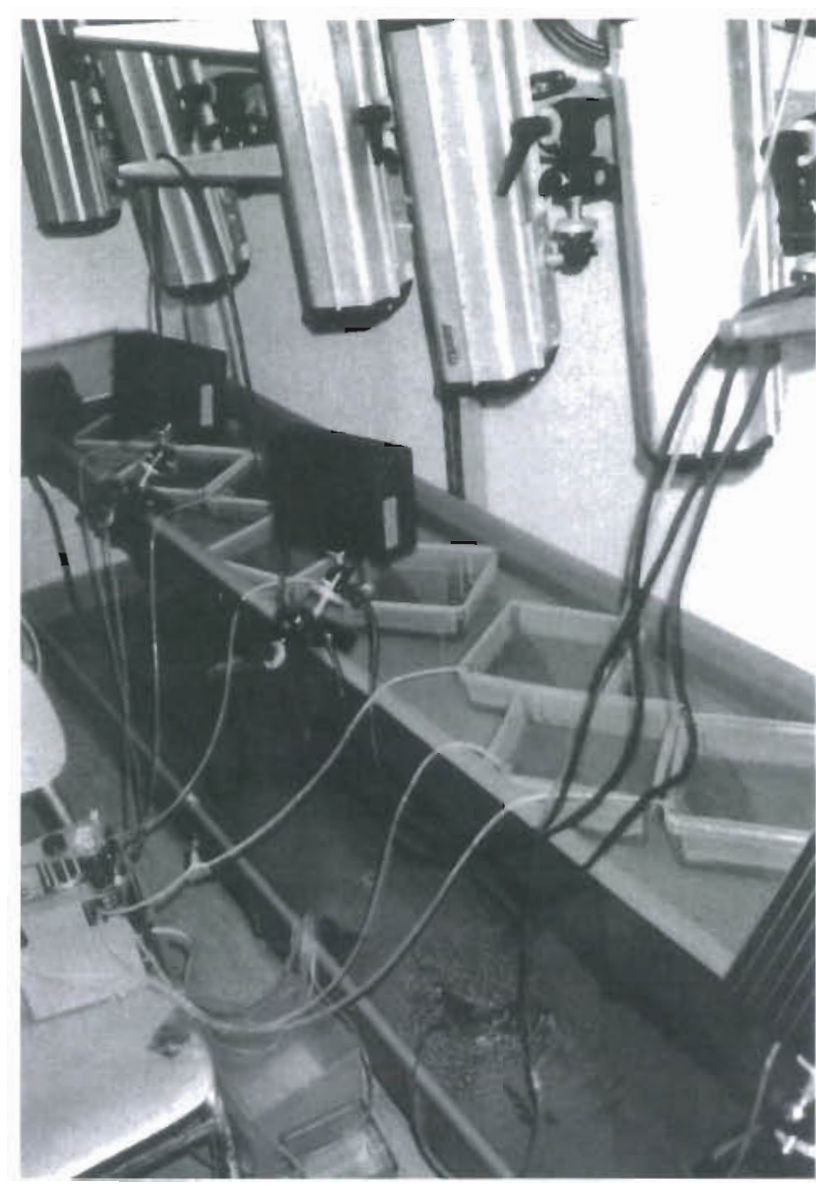

Fig. 1. Experimental set-up. Aquaria were connected to sea or prepared water (lower trough) via a peristaltic pump. Videocameras were placed above the aquaria. Infrared light emittors (to the left of the aquaria) made video-recording possible in the dark

water was pumped into the aquaria in one of the upper troughs, and prepared water into the aquaria in the other upper trough. Water flow into each aquarium, $0.8 \pm 0.1 \mathrm{l} \mathrm{h}^{-1}$, was regulated with a multi-channel peristaltic pump (Alitea, Stockholm, Sweden). The sea water came from $16 \mathrm{~m}$ depth; it was filtered through sand (grain size 0.6 to $0.8 \mathrm{~mm}$ ) and cooled (ca $7{ }^{\circ} \mathrm{C}$, salinity $6.5 \mathrm{psu}$ ) before reaching the troughs and was aerated once in the troughs. Cue water was prepared for each experiment. The fish, unfed isopod and fed isopod experiments were run consecutively, and the experimental equipment was thoroughly cleaned prior to the start of a new experiment to avoid contamination between experiments. Using milk as a tracer, it was shown that the whole water volume of the experimental aquaria was reached by the incoming fluid in less than $10 \mathrm{~min}$.
Twelve video-recording cameras (Ikegami ICD$42 \mathrm{EAC}$ ) sensitive in the infrared region of the light spectrum were placed above the aquaria (Fig. 1). Lamps emitting sufficient infrared light (>880 nm) for the registering cameras were used. The light sensitivity of Monoporeia affinis declines sharply towards the red end of the spectrum (Donner 1971), as does that of Saduria entomon (Lindström et al. 1991), and neither species can detect infrared light (Donner \& Lindström 1980, Lindström et al. 1991). Time-lapse recording started prior to the addition of $S$. entomon. A sequential video-switcher activated the recording cameras in turn from camera 1 to 12 and then repeated the procedure. Recording time was registered on the videotape, and intervals between moving pictures as seen on the TV monitor were 2.2 or $4.1 \mathrm{~s}$, respectively, for $24 \mathrm{~h}$ and $48 \mathrm{~h}$ long time-lapse recordings. It was not possible to quantify accurately the number of amphipods swimming at a given time, hence swimming activity was registered as present as soon as a single amphipod was seen swimming. As the recording time was registered on the videotape it was possible to determine the duration of the different activities of the animals

When terminating the experiments, the sediment was sieved, and amphipods retained on a $500 \mu \mathrm{m}$ mesh metal net were preserved in $4 \%$ buffered formalin and stained with Rose Bengal. The length of the amphipods was measured on straightened out animals from the tip of the rostrum to the end of the last urosome segment with an image analyzing system (Zeiss, MOP videoplan). Isopod length was measured from the anterior end of the head shield to the tip of the telson.

Fish experiment. In order to test whether chemical substances from predatory fish influence the behaviour of Saduria entomon, and uitimately the survival of its amphipod prey (Monoporeia affinis), the following 4 treatments were set up: (1) $S$. entomon and $M$. affinis in untreated sea water ( 8 aquaria), (2) $S$. entomon and $M$. affinis in fish-treated water ( 8 aquaria), (3) controls with $M$. affinis alone in untreated sea water (3 aquaria), and (4) $M$. affinis in fish-treated water (3 aquaria). This gave a total of 22 aquaria, 12 of which

Table 1 Experimental set-up of the fish experiment. Fish were not fed during the experiment

\begin{tabular}{|lcccc|}
\hline Treatment & $\begin{array}{c}\text { No. of } \\
\text { aquaria }\end{array}$ & $\begin{array}{c}\text { No. } \\
\text { filmed }\end{array}$ & $\begin{array}{c}\text { No. of } S . \\
\text { entomon } \\
\text { aquarium }\end{array}$ & $\begin{array}{c}\text { No. of } M \text {. } \\
\text { affinis } \\
\text { aquarium }^{-1}\end{array}$ \\
\hline Sea $\mathrm{H}_{2} \mathrm{O}+\mathrm{S}$. entomon $+M$. affinis & 8 & 6 & 1 & 30 \\
Fish $\mathrm{H}_{2} \mathrm{O}+\mathrm{S}$. entomon $+M$. affinis & 8 & 6 & 1 & 30 \\
Sea $\mathrm{H}_{2} \mathrm{O}+M$. affinis & 3 & 0 & - & 30 \\
Fish $\mathrm{H}_{2} \mathrm{O}+M$. affinis & 3 & 0 & - & 30 \\
\hline
\end{tabular}


were video-recorded (6 each of treatments 1 and 2) (Table 1). Video-recordings were made in $48 \mathrm{~h}$ time-lapse mode for a total of $72 \mathrm{~h}$.

Thirty adult Monoporeia affinis $(\bar{x} \pm \mathrm{SE}$, $7.8 \pm 0.2 \mathrm{~mm}$ long) were gently added to each box at the start of the experiment. One Saduria entomon $(30 \pm 1 \mathrm{~mm})$ per aquarium was added in treatments 1 and 2 .

Fish-treated water was prepared in one of the lower 140 l troughs by keeping 3 Myoxocephalus scorpius (total weight ca $1 \mathrm{~kg}$ ) in sea water for $24 \mathrm{~h}$ prior to the start and during the entire fish experiment. Sea water and fish-treated water were refilled twice a day into the troughs (Fig, 1). The fish-treated water for refilling was prepared in 3 troughs, each of which held nothing but 1 short-horned sculpin (ca $0.3 \mathrm{~kg}$ ) in 451 sea water.

Unfed isopod experiment. The experiment was designed to test whether Monoporeia affinis reacted to water which had contained unfed Saduria entomon. $M$. affinis were assigned at random to either of 2 treatments: water from unfed isopods, or untreated sea water. Each treatment had 8 aquaria, 6 of which were video-recorded (for $22 \mathrm{~h}$ ) as above (Table 2). Thirty $M$. affinis (average size $7.8 \pm 0.2 \mathrm{~mm}$ ) were added to each aquarium. The unfed isopod-treated water was prepared by keeping unfed isopods (37 specimens, total weight ca $24 \mathrm{~g}$ ) in natural sea water in one of the lower $140 \mathrm{l}$ troughs (Fig. 1) for $48 \mathrm{~h}$ prior to and during the entire experiment. Water was not refilled.

Fed isopod experiment. To test if substances from Saduria entomon killing, eating and digesting Monoporeia affinis affected the behaviour of other $M$. affinis, fed-isopod-treated water, i.e. sea water containing 34 isopods (mean body length ca $30 \mathrm{~mm}$, total weight ca $22 \mathrm{~g}$ ) and 340 amphipods (ca $7.7 \pm 0.2 \mathrm{~mm}$ ) from a $140 \mathrm{l}$ trough, or untreated sea water from another $140 \mathrm{l}$ trough was added to aquaria, each containing $30 \mathrm{M}$. affinis. The aquaria were video-recorded in $24 \mathrm{~h}$ timelapse mode for 22 h ( 8 aquaria per treatment, 6 of which were video-recorded) (Table 3). In the fed-isopod-treated water trough, isopods were fed $M$. affinis $2 \mathrm{~d}$ prior to the experiment and during the entire experiment. During this $3 \mathrm{~d}$ period, a total of 290 amphipods were consumed, i.e. ca 8 per isopod. Water was not refilled.

Statistics. One-factor analysis of variance (ANOVA) was used, except when variance was heterogeneous according to Cochran's or Bartlett's test (balanced or unbalanced treatments respectively). Significant results were followed by the Tukey test for unequal $N$
(= TT). When homogeneity of variances could not be obtained through data transformation, the MannWhitney $U$-test was used. A paired $t$-test tested for differences in the light/dark activity of Saduria entomon. Amphipod activity data was analysed using 2-factor repeated measures ANOVA. Calculations based on a pilot study indicated that 8 replicates would be needed to achieve a power of 0.8 in order to detect a difference of at least $30 \%$ in amphipod survival (Zar 1984).

\section{RESULTS}

\section{Fish experiment}

During the $72 \mathrm{~h}$ experimental period, Saduria entomon spent only $0.8 \pm 0.3 \%$ (36 min) of its time at the sediment surface in fish-treated water, but significantly longer, $7.9 \pm 3.3 \%$ (340 min), in the sea water treatment (ANOVA, $F_{1,9}=13.8, p=0.005$ ). One $S$. entomon in the sea water treatment moulted and was excluded from the analysis. No differences in activity during the light and dark periods were found within the fish treatment (paired $t$-test, $\mathrm{p}>0.05$ ) or within the sea water treatment (paired t-test, $p>0.05$ ) (Fig. 2).

Survival of Monoporeia affinis in the controls for the fish ( $29 \pm 1$ specimens) and sea water ( $29 \pm 1$ specimens) treatments and in the Saduria entomon with fish-treated water treatment ( $26 \pm 1$ specimens) was significantly better than in the $S$. entomon with sea water treatment $\left(19 \pm 2\right.$ specimens) (ANOVA, $F_{3,17}=$ 12.21, $p=0.0002 ; \mathrm{TT}, \mathrm{p}<0.05$ ) (Fig. 3). 


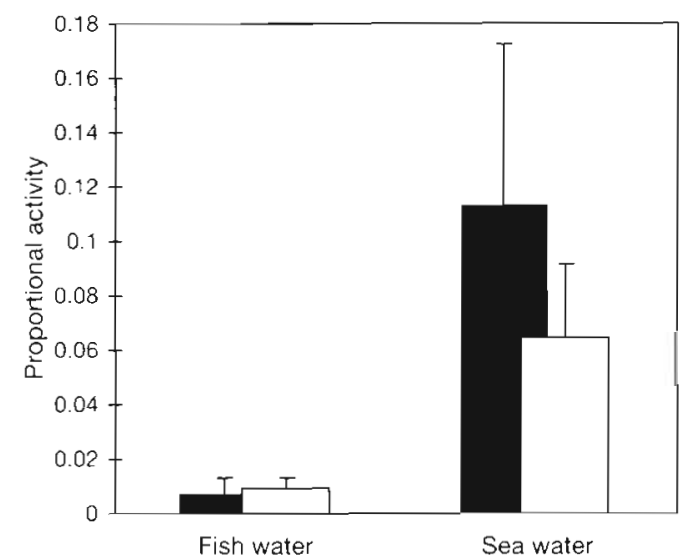

Fig. 2. Proportional activity of Saduria entomon in the fish experiment. Mean + standard error of the mean. Black denotes the dark period and white the light period

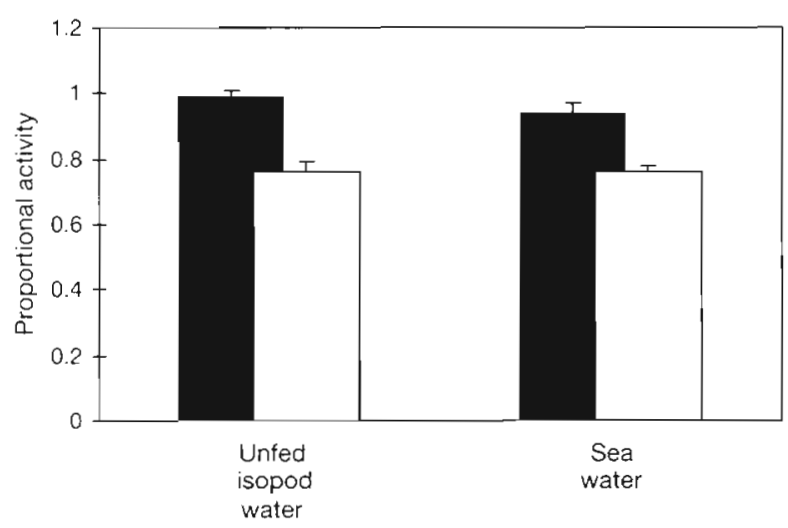

Fig. 4. Monoporeia affinis proportional activity in the dark and light periods in the unfed isopod experiment. Mean + standard error of the mean. Black denotes the dark period and white the light period

\section{Unfed isopod experiment}

Amphipod survival was high, $97 \pm 1 \%$, in both treatments (ANOVA, $F_{1,14}=0.43, \mathrm{p}=0.52$ ), with a similar swimming activity, $82 \pm 1 \%$ (of the total experimental timel in sea water and $83 \pm 2 \%$ in unfed-isopod-treated water (Table 4); and for both treatments swimming was significantly more intense in the dark (Fig. 4, Table 4). All Saduria entomon survived.

\section{Fed isopod experiment}

Amphipod survival was $100 \%$ in sea water and $96 \pm$ $2 \%$ in fed-isopod-treated water (Mann-Whitney $U$ test, $p=0.003, n=16$ ). All isopods survived. Amphipod swimming activity was significantly affected by the origin of the added water (Table 5). In fed-isopod-

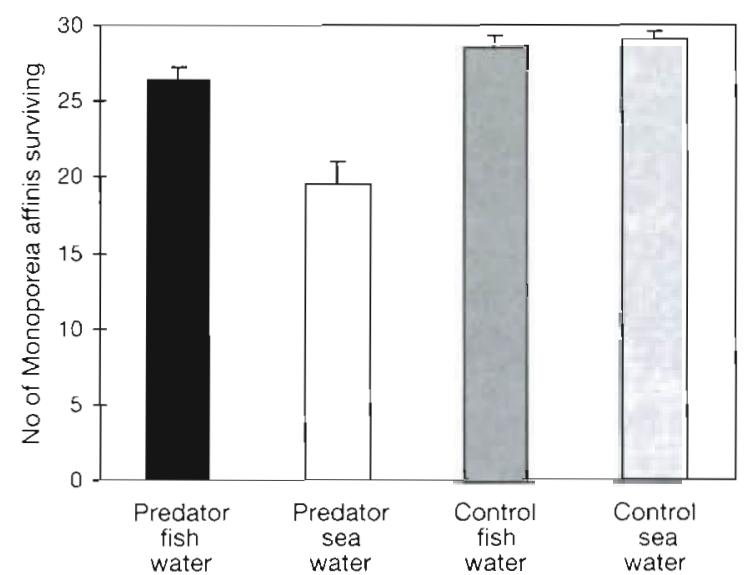

Fig. 3. Number of Monoporeia affinis surviving in the presence and absence (control) of Saduria entomon in the fish experiment. Mean + standard error of the mean

treated water, swimming was reduced, occurring for only $16 \pm 4 \%$ of the total experimental time, while in sea water the corresponding figure was $72 \pm 6 \%$. In both treatments, Monoporeia affinis was proportionally more active during the dark period (Fig. 5, Table 5).

\section{DISCUSSION}

Predation risk often affects prey behaviour (Alexander \& Covich 1991b, Legault \& Himmelman 1993), and potential prey often shift into safer habitats (Dill 1987, Lima \& Dill 1990, Sih 1993, Jachner 1995) or spatially within habitats (Phillips 1977, Alexander \& Covich 1991b, Dix \& Hamilton 1993) to avoid predation. Risk of predation usually reduces locomotory activity of prey (Lima \& Dill 1990, Sih 1993), which improves the chance of avoiding detection by the predator. Monoporeia affinis and Saduria entomon were both less mobile in the presence of odour from their natural predators, and both spent more time within the sediment.

The fish experiment indicates that Saduria entomon reacts to perceived predation risk with decreased

Table 4. Unfed isopod experiment. Two-factor repeated measures ANOVA performed on Monoporeia affinis proportional activity during a light or dark period in unfed-isopod-treated water or sea water (cue)

\begin{tabular}{|lcrc|}
\hline Source of variation & df & $F$ & $p$ \\
\hline Cue & 1 & 0.79 & 0.4159 \\
Light/dark & 1 & 54.94 & 0.0007 \\
Cue $\times$ light/dark & 1 & 0.17 & 0.6961
\end{tabular}




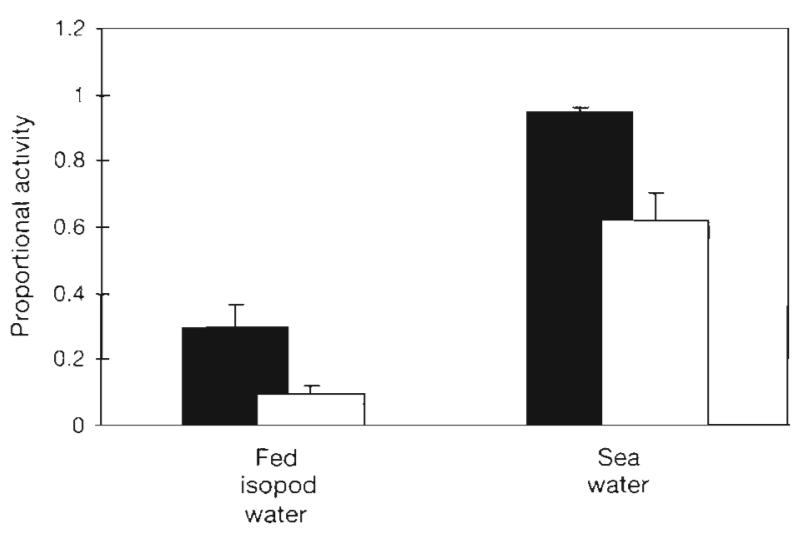

Fig. 5. Monoporeia affinis proportional activity in the dark and light periods in the fed isopod experiment. Mean + standard error of the mean. Black denotes the dark period and white the light period

Table 5. Fed isopod experiment. Two-factor repeated measures ANOVA performed on Monoporeia affinis proportional activity in a light or dark period in fed-isopod-treated water or sea water (cue)

\begin{tabular}{|lrrc|}
\hline Source of variation & df & $F$ & $p$ \\
\hline Cue & 1 & 184.50 & 0.00004 \\
Light/dark & 1 & 62.04 & 0.00053 \\
Cue $\times$ light/dark & 1 & 1.19 & 0.32570 \\
\hline
\end{tabular}

activity. When exposed to fish-treated cue water, the activity of $S$. entomon at the sediment surface decreased; Leonardsson (1991) found a similar reaction for small $S$. entomon exposed to chemical cues from predatory larger conspecifics. In spite of the depressed activity of $S$. entomon, amphipods were still eaten, albeit at a slower rate than when fish odour was absent

When Saduria entomon was burrowed in the sediment, the antennae and head were occasionally seen, but the body was mostly hidden. In sea water, antennae were seen more frequently and for longer periods than in the fish-treated water. Once the antennae had been withdrawn into the sediment, they were very difficult to detect, except when exposed again at the same, or nearly the same, spot where they had been seen earlier. However, movement of a totally burrowed $S$. entomon could sometimes be followed through ridgelike structures 'moving' over the sediment surface, with some amphipods escaping from the sediment just ahead of the moving isopod. When neither parts of the body nor ridgelike structures were seen, the isopods remained undetected until appearing again at the sediment surface. No estimates of antennal exposure or of behaviour within the sediment can thus be presented.
Saduria entomon in sea water stayed mainly just below the sediment surface, with flicking antennae showing, thus increasing the exposure of its chemical receptors to odour cues (Schmitt \& Ache 1979). Shorthorned sculpins are visual foragers with a diel foraging cycle, being diurnal in winter and nocturnal in summer (Westin \& Aneer 1987). The sculpins do not search for food within the sediment, but use an ambush technique (L. Westin pers. comm.). Foraging methods used by $S$, entomon include ambushing, or sit and wait, behaviour; sediment surface food search (fast active hunt, i.e. when the isopod swims or moves on, or just below, the sediment surface with its body showing); and burrowing food search (slow active hunt, used when food is searched for at depth in the sediment, with the body hidden in the sediment) (Green 1957, Pynnönen 1985, Ejdung \& Bonsdorff 1992). The foraging methods used by $S$ entomon change with exposure to fish-treated cue water, suggesting a perception of increased predation risk. Although quick rushes over the sediment surface might have provided $S$. entomon with food, the isopod seemed to search for food mainly within the sediment when exposed to fish odour, video sequences sometimes showing movements of $S$. entomon within the sediment. The change in behaviour, and use of a habitat spatially separated from that normally foraged in by short-horned sculpins, should lower encounter rates between short-horned sculpins and $S$. entomon and increase isopod survival. However, predator avoidance behaviours often lower food encounter rates (Sih 1993), while energy continues to be used for maintenance and locomotion (Norberg 1977). Evidently, S. entomon searched for prey down in the sediment, and the number of prey consumed decreased, as often found when predatory fish are present (Holomuzki \& Short 1988).

As sculpins in nature include amphipods in their diet (Westin 1970), they directly affect amphipod survival. This laboratory study of a benthic 3-trophic-level system, with fish odour present during the whole experiment, reflects a near distance predator-prey situation in the field. In the experiment, the presence of fish odour had an indirect positive effect on amphipod survival, since the activity of the predatory isopod decreased. Saduria entomon in the experiment could only avoid the perceived predator by burrowing and decreasing its activity, but in nature another avoidance behaviour, emigration, is possible (Sparrevik \& Leonardsson 1995), and probably important.

Recently, the first steps in the characterization of kairomones released by planktivorous fishes have been made (Loose et al. 1993, von Elert \& Loose 1996). The specific substances released in my experiment are unknown. Additional research is needed to determine 
the chemical composition of the substances, their natural concentrations and their rate of degradation.

Recognition of chemical cues emitted by predators or injured conspecifics may increase prey survival, and many aquatic organisms possess this ability (Phillips 1978, Hugie et al. 1991, Covich et al. 1994, Duval et al. 1994). Large crustaceans obtain chemical information by producing currents (Atema 1988), and Monoporeia affinis may receive a continuous flow of information on predation risk from chemical cues, which enter its burrow with the currents created by its beating pleopods. The swimming activity of $M$. affinis decreased drastically in water with cues from Saduria entomon fed $M$. affinis, indicating that $M$. affinis is able to evaluate the degree of risk connected with the chemical information received. The 'dietary history' of a predator often affects prey responses (Duval et al. 1994). Lack of response to a nonforaging or starving predator has been reported also in the sea urchins Strongylocentrotus purpuratus, in the freshwater snails Physella virgata and P. gyrina and the cladoceran Daphnia galeata mendotae (Phillips 1978, Crowl \& Covich 1990, Stirling 1995, Turner 1996).

The Baltic benthic ecosystem has been considered as fairly simple, due to its low macro- and meiofaunal diversity (Elmgren 1978). Large areas in the Baltic are covered by fine grained sediments, over which chemoreception works better than on coarse (ca 2 to $3 \mathrm{~mm}$ ) substrates (Weissburg \& Zimmer-Faust 1993). Taking chemical predator-prey interactions into consideration will increase the complexity of interactions in this system. This laboratory study demonstrates that the predator-prey interactions investigated are affected by a variety of chemical cues from predators and prey. Further studies are required to evaluate better the importance of such chemical cues in the field, and of indirect interactions between species caused by chemical cues, in this community.

Acknowledgements. I thank Barbro Söderlund for skilful technical assistance in the field and laboratory, Carl André and Dennis Swaney for statistical discussions, B.-O. Jansson for providing research facilities at the Askö Laboratory, the staff at the Askö Laboratory, and the Norrby Laboratory for providing isopods. Ragnar Elmgren, Christer Wiklund and anonymous reviewers gave critical comments on the manuscript. This work was supported by grants from the Stockholm Centre for Marine Research, and Swedish Academy of Science (Hierta-Retzius foundation) to G.E., and by the Swedish Natural Science Research Council to R. Elmgren.

\section{LITERATURE CITED}

Abrahams MV (1994) Risk of predation and its influence on the relative competitive abilities of two species of freshwater fishes. Can J Fish Aquat Sci 51:1629-1633

Abrahams MV, Dill LM (1989) A determination of the energetic equivalence of the risk of predation. Ecology 70 : $999-1007$
Alexander JE, Covich AP (1991a) Predator avoidance by the freshwater snail Physella virgata in response to the crayfish Procambarus simulans. Oecologia 87:435-442

Alexander JE, Covich AP (1991b) Predation risk and avoidance behavior in two freshwater snails. Biol Bull (Woods Hole) 180:387-393

Aneer G (1975) Composition of food of the Baltic herring (Clupea harengus $v$. membras L.), fourhorn sculpin (Myoxocephalus quadricornis L.) and eel-pout (Zoarces viviparus L.) from deep soft bottom trawling in the Askö-Landsort area during two consecutive years. Merentutkimuslaitoksen Julk 239:146-154

Appelberg M, Söderbäck B, Odelström T (1993) Predator detection and perception of predation risk in the crayfish Astacus astacus L. Nord J Freshwat Res 68:55-62

Appleton RD, Palmer AR (1988) Waterborne stimuli released by predatory crabs and damaged prey induce more predator-resistent shells in marine gastropods. Proc Natl Acad Sci USA 85:4387-4391

Atema $J$ (1988) Distribution of chemical stimuli. In: Atema J, Fay RR, Popper AN, Tavolga WN (eds) Sensory biology of aquatic animals. Springer-Verlag, New York, p 29-56

Blomqvist S, Lundgren L (1996) A sled for sampling soft bottoms. Helgoländer Meeresunters 50:453-456

Burrows MT, Hughes RN (1991) Optimal foraging decisions by dogwhelks, Nucella lapillus (L.): influences of mortality risk and rate-constrained digestion. Funct Ecol 5:461-475

Busdosh M, Robilliard GA, Tarbox K, Beehler CL (1982) Chemoreception in an arctic amphipod crustacean: a field study. J Exp Mar Biol Ecol 62:261-269

Cederwall H (1990) Övervakning av mjukbottenfauna i Östersjöns kustområde. Rapport från verksamheten 1989. SNV rapport 3796. ISBN 91-620-3796X, ISSN 0282-7298

Covich AP, Crowl TA, Alexander JE Jr, Vaughn CC (1994) Predator-avoidance responses in freshwater decapod-gastropod interactions mediated by chemical stimuli. J North Am Benthol Soc 13:283-290

Crowl TA, Covich AP (1990) Predator-induced life-history shifts in a freshwater snail. Science 247:949-951

Dill LM (1987) Animal decision making and its ecological consequences: the future of aquatic ecology and behaviour. Can J Zool 65:803-811

Dill LM, Fraser AHG (1984) Risk of predation and the feeding behavior of juvenile coho salmon (Oncorhyncus kisutch). Behav Ecol Sociobiol 16:65-71

Dix TL, Hamilton PV (1993) Chemically mediated escape behavior in the marsh periwinkle Littoraria irrorata Say. J Exp Mar Biol Ecol 166:135-149

Dodson SI, Crowl TA, Peckarsky BL, Kats LB, Covich AP, Culp JM (1994) Non-visual communication in freshwater benthos: an overview. J North Am Benthol Soc 13:268-282

Donner KO (1971) On vision in Pontoporeia affinis and P. femorata (Crustacea, Amphipoda). Commentat Biol Soc Sci Fenn 41:1-17

Donner KO, Lindström M (1980) Sensitivity to light and circadian activity of Pontoporeia affinis (Crustacea, Amphipoda). Ann Zool Fenn 17:203-212

Duval MA, Calzetta AM, Rittschof D (1994) Behavioral responses of Littoraria irrorata (SAY) to waterborne odors. J Chem Ecol 20:3321-3334

Ejdung G, Bonsdorff E (1992) Predation on the bivalve Macoma balthica (L.) by the isopod Saduria entomon (L.): laboratory and field experiments. Mar Ecol Prog Ser 88: $207-214$

Elmgren R (1978) Structure and dynamics of Baltic benthos communities with particular reference to the relationship between macro- and meiofauna. Kieler Meeresforsch 4:1-22 
Folt C, Goldman CR (1981) Alielopathy between zooplankton: a mechanism for interference competition. Science 213: $1133-1135$

Gilliam JF, Fraser DF (1987) Habitat selection under predation hazard: test of a model with foraging minnows. Ecology $68: 1856-1862$

Green J (1957) The feeding mechanism of Mesidoted entomon (Linn.) (Crustacea: Isopoda). Proc Zool Soc Lond 129: 245-254

Haahtela I (1990) What do Baltic studies tell us about the isopod Saduria entomon (L.)? Ann Zool Fenn 27:269-278

Hill C, Elmgren R (1987) Vertical distribution in the sediment in the co-occurring benthic amphipods Pontoporeia affinis and P. femorata. Oikos 49:221-229

Holomuzki JR, Short TM (1988) Habitat use and fish avoidance behaviors by the stream-dwelling isopod Lirceus fontinalis. Oikos 52:79-86

Houtman R, Dill LM (1994) The influence of substrate color on the alarm response of tidepool sculpins (Oligocottus maculosus, Pisces, Cottidae). Ethology 96:147-154

Hughes RN (1980) Optimal foraging theory in the marine context. Oceanogr Mar Biol Annu Rev 18:423-481

Hugie DM, Thuringer PL, Smith RJ (1991) The response of the tidepool sculpin, Oligocottus maculosus, to chemical stimuli from injured conspecifics, alarm signalling in the Cottidae (Pisces). Ethology 89:322-334

Jachner A (1995) Chemically-induced habitat shifts in hleak (Alburnus alburnus L.). Arch Hydrobiol 133:71-79

Kaufman RS (1994) Structure and function of chemoreceptors in scavenging lysianassoid amphipods. J Crustac Biol 14: $54-71$

Larsson P, Dodson S (1993) Invited review. Chemical communication in planktonic animals. Arch Hydrobiol 129: $129-155$

Laverack MS, Ardill DJ (1965) The innervation of the aesthetasc hairs of Panulirus argus. $Q$ J Microsc Sci 106 : $45-60$

Legault C, Himmelman JH (1993) Relation between escape behaviour of benthic marine invertebrates and the risk of predation. J Exp Mar Biol Ecol 170:55-74

Leonardsson K (1991) Effects of cannibalism and alternative prey on population dynamics of Saduria entomon (Isopoda). Ecology 72:1273-1285

Lima SL, Dill LM (1990) Behavioral decisions made under the risk of predation: a review and prospectus. Can J Zool 68: $619-640$

Lindström M (1991) Factors affectıng the horizontal migration of the amphipod Pontoporeia affinis Lindström. I. Recording method and response to water currents. J Exp Mar Biol Ecol 150:149-162

Lindström M, Fortelius W, Meyer-Rochow VB (1991) Exposure to bright light has little effect on eye sensitivity and ultrastructure of Saduria entomon (Crustacea, Isopoda, Valvifera). Zool Sci 8:653-663

Lindström M, Lindström A (1980) Swimming activity of Pontoporeia affinis (Crustacea. Amphipoda)-seasonal variations and usefulness for environmental studies. Ann Zool Fenn 17:213-220

Lockwood APM, Croghan PC (1957) The chloride regulation of the brackish and fresh-water races of Mesidotea entomon (L.). J Exp Biol 34:253-258

Loose CJ, von Elert E, Dawidowicz P (1993) Chemicallyinduced diel vertical migration in Daphnia: a new bioassay for kairomones exuded by fish. Arch Hydrobiol 126 $329-337$

Lopez G, Elmgren R (1989) Feeding depths and organic absorption for the deposit-feeding benthre amphipods
Pontoporeia affinis and Pontoporeia femorata. Limnol Oceanogr 34:982-991

Mangel M, Clark CW (1986) Towards a unified foraging theory. Ecology 5:1127-1138

McNamara JM, Houston AI (1986) The common currency for behavioral decisions. Am Nat 127:358-378

McNamara JM, Houston AI (1992) Risk-sensitive foraging a review of the theory. Bull Math Biol 54:355-378

Norberg $\AA$ (1977) An ecological theory on foraging time and energetics and choice of optimal food-searching method. J Anim Ecol 46:511-529

Phillips DW (1977) Avoidance and escape responses of the gastropod mollusc Olivella biplicata (Sowerby) to predatory asteroids. J Exp Mar Biol Ecol 28:77-86

Phillips DW (1978) Chemical mediation of invertebrate defensive behaviors and the abulity to distinguish between foraging and inactive predators. Mar Biol 49:237-243

Pynnönen K (1985) The structure of long distance (antennular) chemoreceptors in Saduria entomon (L.), Isopoda, and their role in feeding behaviour. Annl Zool Fenn 22:423-432

Rittschof D (1993) Body odors and neutral-basic peptide mimics: a review of responses by marine organisms. Am Zool $33: 487-493$

Rochette R, Hamel JF, Himmelman JH (1994) Foraging strategy of the asteroid Leptasterias polaris: role of prey odors, current and feeding status. Mar Ecol Prog Ser 106:93-100

Schmitt BC, Ache BW (1979) Olfartion: rosponses of a decapod crustacean are enhanced by flicking. Science 205 : $204-206$

Sih A (1982) Foraging strategies and the avoidance of predation by an aquatic insect, Notonecta hoffmanni. Ecology 63:786-796

Sih A (1986) Antipredator responses and the perception of danger by mosquito larvae. Ecology 67:434-441

Sih A (1993) Effects of ecological interactions on forager diets composition, predation risk, parasitism and prey behaviour. In: Hughes RN (ed) Diet selection: an interdisciplinary approach to foraging behaviour. Blackwell, Oxford, p $182-211$

Sparrevik E, Leonardsson K (1995) Effects of large Saduria entomon (Isopoda) on spatial distribution of their small $S$. entomon and Monoporeia affinis (Amphipoda) prey. Oecologia 101:177-184

Stirling G (1995) Daphnia behaviour as a bioassay of fish presence or predation. Funct Ecol 8:778-784

Turner AM (1996) Freshwater snails alter habitat use in response to predation. Arim Behav 51:747-756

Vadas RLS, Burrows MT, Hughes RN (1994) Foraging strategies of dogwhelks, Nucella lapillus (L.): interacting effects of age, diet, and chemical cues to the threat of prectation. Oecologia 100:439-450

von Elert E, Loose CJ (1996) Predator-induced diel vertical migration in Daphnia: enrichment and preliminary chemical characterization of a kairomone exuded by fish. J Chem Ecol 22:885-895

Weissburg MJ, Zimmer-Faust RK (1993) Life and death in moving fluids: hydrodynamic effects on chemosensorymediated predation. Ecology $74: 1428-1443$

Westin L (1970) The food ecology and the annual food cycle in the Baltic population of fourhorn sculpin, Myoxocephalus quadricornis (L.). Pisces. Rep Inst Freshwat Res Drottningholm 50:168-210

Westin L, Aneer G (1987) Locomotor activity patterns of nineteen fish and five crustacean species from the Baltic Sea. Environ Biol Fishes 20:49-65

Zar JH (1984) Biostatistical analysis, 2nd ed.n. Prentice Hall, Englewood Cliffs, NJ 